\title{
ОСНОВНЫЕ СУБЪЕКТЫ ПОЛИТИЧЕСКИХ ОТНОШЕНИЙ В ВОСТОЧНОЙ ГАЛИЦИИ В УСЛОВИЯХ ПОДЪЕМА УКРАИНСКОГО ЛЕГАЛЬНОГО ПОЛИТИЧЕСКОГО ДВИЖЕНИЯ В КОНЦЕ 1920 - НАЧАЛЕ 1930-х гГ.
}

\begin{abstract}
Аннотация: Статья посвящена анализу основных субъектов политических отношений в Восточной Галиции на рубеже 1920-1930-х гг. Целью работы является структурирование этих субъектов с тем, чтобы определить роль и место в политических отношениях в регионе в условиях политики государственной ассимиляци украинского населения, проводимой польскими властями в указанные годы. При проведении работы применялись методы анализа и обобщения, дедукиии, абстрагирования. В ходе исследования было установлено следующее. Вопервых, на рубеже 1920-1930-х г2. политические отнотения в Восточной Галиции были заплетены в сложный узел, будучи наполнены многими противоречиями. По большому счету, они носили многоуровневый характер, ранжируясь в значительной степени в соответствии с имевщей место в регионе в рассматриваемые годы этносоииальной структурой населения. Во-вторых, суть политических отношений в Восточной Галиции на рубеже 1920-1930-х г2. можно определить как проявление диалектической борьбы двух противоположностей-тенденций к легализации и, вместе с тем, - маргинализации украинского национального политического движения в условиях наибольшего подъема его легального сегмента. Несмотря на определенные благоприятные шансы, точка соприкосновения между главными субъектами политических отнотений так и не была найдена.

Ключевые слова: Политология, субъекты политических отношений, Восточная Галиция, межвоенный период, политическое движение, национальное движение, украинџь, партия, соииально-политические факторы, Майский переворот
\end{abstract}

$\Pi$ олитические отношения - один из важнейших параметров политического анализа. Их определяют как взаимодействие социальных групп, личностей, социальных институтов по поводу устройства и управления обществом. Политические отношения возникают, когда потребность в управлении и властном регулировании социальных процессов и отношений начинает осуществляться при активном участии государства и связаны с распределением в обществе власти, прав и полномочий, с разграничением предметов ведения центра и мест. К политическим отношениям относятся отношения между: государственными органами и учреждениями (например, между правительством и парламентом); государством и социальными группами (например, между государством и предпринимателями); государством и негосударственными общественными организациями и движениями (например, между государством и церковью); политическими партиями, а также между политическими партиями и неполитическими организациями (например, между партиями и профсоюзами); государством и гражданами; различными государствами на международной аре- не; государством и международными политическими объединениями. Их предметом является власть.

Проявления обозначенных выше взаимосвязей могут быть различными: отношения соперничества, конкуренции (например, между политическими партиями); взаимной ответственности (например, между гражданином и государством); поддержки (например, между избирателями и определенной партией); сотрудничества (например, между определенной партией и профсоюзами); союза (скажем, несколько государств); конфликта (например, между государствами или государством и той или иной социальной группой) и др.

В основе этих отношений лежат интересы и цели, совпадение или расхождение которых предопределяет развитие взаимодействия участников политической жизни. Характер взаимоотношений зависит от экономических и социальных факторов, от политической культуры общества, а также от политической воли субъектов политики.

Рассматриваемая в настоящей статье проблема как самостоятельный предмет политологического иссле- 
дования до сих пор изучена недостаточно. В имеющихся же работах, в которых она, так или иначе, поднимается, акцент делается на этнический фактор этих отношений, а не собственно политическую их составляющую. При этом, в польской науке они освещаются с позиции законного, исторически обусловленного примата польского населения Восточной Галиции, в украинской же - поляки традиционно рассматриваются как «оккупанты» на исконно украинской территории. Фактическое же их преобладание в политической жизни восточно-галицкого региона объясняется искусственными причинами, не вытекающими из объективного соотношения в нем политических сил.

Цель данной статьи заключается в том, чтобы, проведя политологический анализ ситуации, попытаться на основании объективных факторов рассмотреть деятельность основных субъектов политических отношений в Восточной Галиции на рубеже 1920 - 1930-х гг. Ключевым аспектом в этом анализе в указанное время является синхронный - как с польской, так и с украинской стороны, - подъем политического движения. При этом, в контексте дискриминационной в течение большей части межвоенного периода политики польских властей в отношении украинского населения Восточной Галиции, период 1927 - 1933 гг. был, в сравнении с другими этапами истории межвоенной Польши, наиболее благоприятным временем для украинского легального политического движения. Кроме того, значительный интерес представляет собой проблема отношений последнего с русинским (русским) политическим движением, также набравшим в рассматриваемые годы заметные, хотя и значительно более скромные, объемы. Причем, разделение восточнославянского общественно-политического движения на эти два «крыла» достаточно активно поддерживалось польскими властями с целью не допустить их объединения в единый лагерь, функционирующий на основе общей платформы.

Специфику политических отношений в Восточной Галиции в 1927 - 1933 гг. определял целый ряд социально-политических факторов, а именно: дифференциация политических сил не только по идейному, но и по национальному признаку, что всячески поддерживалось польскими властями; сильнейшая неравномерность уровня сознательной вовлеченности городского и сельского населения в политическую жизнь и политические процессы, причем, преобладающая часть жителей региона воспринимала политику и субъекты политических отношений постольку, поскольку они отвечали их социальным потребностям; неодинаковый уровень зрелости украинского, русского (русинского) и польского политических движений, что проявлялось в таких аспектах, как значительно большая организационная раздробленность первого, нежели остальных двух, недолговечность многих политических организаций, образованных после падения Австро-Венгрии юридическое и фактическое политическое неравноправие польского и украинского населения, лишенного возможности занимать любые должности в госаппарате восточно-галицких воеводств выше местного уровня; неравенство в статусе польского и украинского языка; тяжелая ситуация с украинским национальным образованием, в частности, отсутствие украинских вузов и серьезные ограничения на получение украинцами образования высоких ступеней; аграрное перенаселение, на которое накладывалась политика наделения земельными наделами польских военных колонистов; значительно более низкий уровень жизни украинских рабочих в сравнении с положением их коллег в «коренной Польше»; ассимиляционная политика польского правительства, возобладавшая в середине 1920-х гг. и вызвавшая виток подъема нелегального националистического и коммунистического движения в регионе, которое привлекло многих представителей активной молодежиㄹ, при более благоприятных условиях пополнившей бы ряды легального украинского политического движения; заметное влияние на политическую жизнь и политическое сознание украинского населения Украинской Греко-Католической Церкви и лично её главы митрополита Андрея Шептицкого.

Основной параметр политических отношений, который мы рассмотрим в настоящей статье, - это отношения между государством и политическими организациями и между последними.

До провозглашения независимости Польши в 1918 г. политические отношения между польскими и украинскими силами Восточной Галиции не отличались особой диссонансностью. Однако, после 1 ноября 1918 г. началась первая в XX столетии польско-украинская война. Несо-

\footnotetext{
${ }^{1}$ Не следует преувеличивать данный фактор, поскольку в течение всего времени пребывания галицких украинцев в составе межвоенной Польши властями в отношении их использовался огромный административный ресурс и, нередко, прямые репрессии на политической платформе.

2 Наибольшие темпы данный процесс приобретет во второй половине 1930-х гг.
} 


\section{Политика и общество 2 (98) • 2013}

мненно, она задала общий тон польско-украинским политическим отношениям в регионе на последующие десятилетия. После окончательного решения Совета послов Антанты от 1923 г. о судьбе восточных территорий, среди восточно-галицких политиков звучали призывы превратить Восточную Галицию в украинскую Ирландию.

В 1920-е гг. на территории Восточной Галиции украинское национальное движение заметно активизировалось. Происходил активный процесс становления партий, кристаллизации основных идейно-политических лагерей, складывания из множества мелких организаций стабильных политических групп с четкой программой. Их центром - также, как и в случае польского, был Львов. Он являлся, без преувеличения, «мировым центром украинского самостийничества» ${ }^{3}$. Именно в Львове находились центры большинства западноукраинских партий. Неудивительно, что у значительной части галицкого общества бытовало мнение, что именно «галичане призваны установить связь между Польшей и Украиной» ${ }^{4}$. При этом, особенность динамики политического развития украинского национального движения в рассматриваемом регионе заключалась в происходившем процессе укрупнения партий. Своего апогея он достиг в 1925 - 1931 гг., когда украинское политическое движение скристаллизировалось в четыре основных направления: леворадикальное (КПЗУ и аграристские партии), национально-демократическое - наиболее масштабное по числу членов и сторонников (УНДО 5 , христианско-демократическое (УКС, УНО) и праворадикальное (УВО-ОУН). Первое и последнее носили нелегальный характер. Если говорить о степени влияния рассмотренных политических групп на украинское население, то о ней говорит одна красноречивая тенденция: на парламентских выборах больше 1\%

\footnotetext{
3 Любимов Л. Д. На рубеже новой Европы. Очерки современной Польши. - Париж, 1930. - С. 55.

${ }^{4}$ Там же. С. 57.

${ }^{5}$ Социальная основа УНДО включала представителей зажиточных слоев деревни, высокооплачиваемую часть интеллигенции (адвокатов, врачей, полонизации часть населения Украины. Именно руководство УНДО одобрило пацификацию в 1930 г. (Макарчук С. А. Отношение к СССР - основной вопрос политической борьбы на Западной Украине (1921 - 1939 гг.) // СССР - оплот мира и дружбы народов. Вестник Львовского университета. Серия общественных наук. Вып. 21. - М., 1982. - С. 139.)
}

голосов набирали только УНДО и УРСП за национал-демократов голосовало обычно не менее $60 \%$ украинцев.

Помимо этого, в Восточной Галиции продолжал действовать ряд украинских молодежных обществ, основанных в конце XIX - начале XX в. - «Луг», «Сокол», «Сич», «Пласт». Они сопротивлялись политике ассимиляции и готовили украинскую молодежь к борьбе за государственную самостоятельность. Следует отметить, что в 1930-е гг. лишь «Сокол» мог легально действовать на территории Восточной Галиции. Особое значение молодежи придавалось потому, что практически весь спектр политических движений видел в ней основной источник пополнения и воспитания смены политически активного населения на перспективу.

«Третьей силой» в политической жизни Восточной Галиции было Русское («москвофильское») движение. Оно вышло из эпохи Первой мировой войны обессиленным и обескровленным, сохраняясь преимущественно в среде значительной части галицкого крестьянства. Его лидером в межвоенный период был В. Ваврик. В начале 1920-х гг. в Варшаве отказались от полонизации галицких русинов с русской идентичностью. Приоритетом стали меры по политической ассимиляции украинцев, что позволило русскому движению развиваться в более спокойных условиях. Прежде всего, необходимо назвать политическую Русскую Народную Организацию (РНО), в 1928 г. переименованную в Русскую Крестьянскую (Селянскую) Организацию (РСО), остававшейся главной политической структурой москвофилов в Галиции. В том же году её численность определялась в 80 - 100 тысяч душ ${ }^{7}$. Идеология РСО традиционно исходила из тезиса о существовании единого русского народа, состоящего из великороссов, малороссов и белорусов, что делало данную партию антагонистом украинских политических организаций Восточной Галиции.

Из других галицко-русских организаций отметим - Русскую аграрную партию, образовательное учреждение - Общество имени М. Качковского ${ }^{8}$, яв-

\footnotetext{
${ }^{6}$ Кугутняк Н. В. - Положение и революционно-освободительная борьба сельскохозяйственного пролетариата Западной Украины в 1929 - 1939 гг.: автореф. дисс. ... канд. ист. наук. - Одесса, 1985. - С. 53

${ }^{7}$ Пашаева Н. М. Очерки истории русского движения в Галичине в XIX - XX вв. - М., 2000. - С. 164.

${ }^{8}$ В 1929 г. Общество располагало зданием во Львове, библиотекой, филиалами в 4 восточногалицких городах, 209 читальнями и в общей сложности 4614 членами.
} 
лявшееся идеологическим антиподом «Просвиты» и её успешным конкурентом на Лемковине, общество «Галицко-русская Матица», научный центр галицко-русского движения - Ставропигийный институт в Львове ${ }^{9}$, Русский Народный Дом. Все они были созданы не позднее 1880 г. В целом, русское движение в межвоенной Галичине не имело политических союзников $^{10}$, но пользовались определенной поддержкой со стороны польских властей, не создававших для него особых препятствий.

В начале 1930-х гг. в украинском общественно-политическом движении оформилось направление, которое охватывало национально-христианские организации, во главе с украинскими греко-католическими иерархами. Это - Украинская Народная Обнова (УНО; до 1931 г. называлась Украинская католическая народная партия; УКНП), основанная епископом Станиславовским Григорием (Хомишиным) в январе 1930 г., находившаяся под протекторатом его, а также О. Назарука, и созданный 5 января 1931 г., в противовес УКНП и набиравшим все большее влияние радикальным националистам, ориенталистский Украинский Католический Союз (УКС) во главе с митрополитом Галицийским, архиепископом Львовским и епископом Каменец-Подольским Андреем (Шептицким).

Цель создания Союза была четко обозначена главой УГКЦ: «Он ставит своей целью оборону веры и Церкви и все те принципы национальные, общественные и политические, которым все католики без исключения должны следовать» ${ }^{11}$. «...Стоя на основе легальности по отношению к государству, посвящение всех своих сил, чтобы на всех отрезках национальной и политической жизни завоевать для нашего народа легальным способом просвещения, культуры, зажиточности... в христианском понимании этого слова...» ${ }^{12}$. По мнению авторитетного исследователя Владимира

\footnotetext{
${ }^{9}$ Ставропигийный Институт являлся преемником знаменитого Успенского Ставропигийного братства, являвшегося форпостом Православия и русской народности на Галицкой Руси 16-18 веков.

${ }^{10}$ Пашаева Н. М. Очерки истории... - С. 166.

${ }^{11}$ Стефанів В. Ставлення Андрея Шептицького до військовополітичної діяльності УВО, ОУН // Україна: культурна спадщина, національна свідомість, державність. Вип. 17/2008. C. 358 .

12 Цит. по Постельжук О. Соціальна база українських угодовських партій Західної України (1918-1939 рр.) // Проблеми історії України: факти, судження, пошуки: Міжвід. зб. наук. пр. Вип. 16(2)/2007. - С. 266.
}

Косика, УНО была четвертой по влиянию на тогдашнее украинское общество легальной партией (после УНДО, УСРП и УСДП) ${ }^{13}$. Тем не менее, она, отстаивая эволюционный принцип развития польско-украинских отношений, не приобрела массового характера.

Еще одним, совершенно новым явлением в общественно-политической жизни украинцев межвоенного периода, была активизация политического женского движения, причем в разных его спектрах. Ключевой организацией здесь был образованный в декабре 1924 г. и функционировавший до июня 1938 г. «Союз украинок». В своем программном документе он продекларировал себя организацией надпартийной, объединяющей в своих рядах женщин разных политических убеждений и партийной принадлежности, категорически отказался от практики создания в рамках партий отдельных женских секций ${ }^{14}$. Также можно отметить «Союз участниц политической деятельности», «Дружину княгини Ольги». В 1931 г. был учрежден Союз женщин-украинок общественной работы. В 1930 г. впервые украинские женщины стали депутатами Сейма и Сената ${ }^{15}$.

Необходимо отметить, что украинские национальные политические организации Западной Украины в целом и Восточной Галиции в частности в своем большинстве были, в лучшем случае, оппозиционными по отношению к польскому режиму, что отражало глубоко укоренившиеся среди украинцев недоверие и недоброжелательность по отношению к полякам ${ }^{16}$, которые, в свою очередь, не испытывали особого расположения к упомянутым организациям. Противоречия значительно возросли после ввода в действие дискриминационных в отношении украинского населения Польши «кресовых законов» С. Грабского от 31 июля 1924 г. Данное обстоятельство являлось камертоном политических отношений в регионе. Впрочем, степень радикальности украинских политических сил в Восточной Галиции в 1920-е гг. еще не

\footnotetext{
${ }^{13}$ Косик В. Україна і Німеччина у Другій світовій війні. - Париж - Нью-Йорк - Львів, 1993. - С. 32

${ }_{14}$ Дядюк М. С. Політизація українського жіночого руху в Галичині: 1921 - 1939 рр.: автореф. дис. ... канд. іст. наук. - Львів, 2002. - С. 12.

15 Раевич T. I. Український жіночий рух на Волині (19211939 роки). Автореф. дис.... канд. іст. наук. - Чернівці, 2006. // URL: http://disser.com.ua/contents/29315.html

${ }^{16}$ Коньков Д. И. Украина и Россия. Краткий очерк истории взаимных отношений. - М., 2005. - С. 64.
} 


\section{Политика и общество 2 (98) • 2013}

достигла своего пика - в значительной степени потому, что в течение 1923 - 1925 гг. подавляющее большинство украинского общества Восточной Галиции в большей или меньшей степени, пусть и вынужденно, адаптировалось к имевшимся жизненным реалиям и интегрировалось в польское государство на индивидуальном уровне ${ }^{17}$. Но это не означало установления социального мира в регионе.

Курс на общий государственный порядок и национальную консолидацию, принятый польскими санационными властями после Майского переворота 1926 г., предполагал корректировку прежней политики в отношении национальных меньшинств в составе Второй Речи Посполитой, в том числе восточнославянских. Это влекло за собой и определенное изменение политической конфигурации. В Восточной Галиции попытку осуществить новый курс предпринял Львовский воевода и одновременно крупный восточно-галицкий землевладелец П. Дунин-Борковский. Он был горячим сторонником идеи «сотрудничества трех наций» ${ }^{18}$, которую попытался провести в жизнь в подчиненном ему воеводстве. Дунин-Борковский считал, что самоуправление и передача максимума власти на места являются основными факторами функционирования польского государства.

Исходя из этих установок, в 1927 - 1928 гг. воевода разработал план устранения объективных причин недовольства украинского населения положением дел - правда, преимущественно в экономических и культурных делах, а не в политической жизни. Дунин-Борковский реализовал его в регионе двух направлениях. Они заключались, с одной стороны, в попытке уменьшения недовольства украинцев путем активизации хозяйственной деятельности и повышения жизненного уровня населения, а с другой - предполагали сглаживание конфликтных ситуаций, возникавших при непосредственных контактах «с некоторыми людьми из фракций, хозяйственных и профессиональной сфер» украинского общества. Таковыми были УНДО и некоторые старорусские группы, показывающие проукраинские тенденции. В то же время, в течение второй половины 1920-х гг. со стороны польских политических кругов происходил «зондаж» политики сотрудничества между УНДО и институтами власти.

${ }^{17}$ Федевич К. К. Галицькі украинці у Польщі 1920 - 1939 pp. (Інтеграція галицьких українців до Польської держави у 1920 - 1930-ті рр.). - К., 2009. - С. 102.

${ }^{18}$ Поляков, украинцев и евреев.
П. Дунин-Борковский завязал сотрудничество с представителями УНДО и русинских общественнополитических кругов в Восточной Галиции с целью устранить изоляционистские настроения и создать общую платформу действий во многих текущих вопросах. Так называемые «черные кофе» - встречи, которые он устраивал с привлечением польских и украинских общественно-политических деятелей, давали возможность реально оценить взаимоотношения между обоими народами в непринужденной атмосфере. Впрочем, они в целом негативно воспринимались по обе стороны: поляки обвиняли П. Дунина-Борковского и его сторонников в «продажности украинцам», сами украинцы, в свою очередь, критиковали тех деятелей, которые встречались с поляками и «продавали Украину» ${ }^{19}$. Расцвет таких встреч-конференций пришелся уже на начало 1930-х годов. Наконец, 15 июня 1928 г. польский Сейм по предложению депутатов украинского парламентского клуба принял закон об официальном введении названия «украинец» и «украинский» вместо употребляемых до этого традиционных названий «русский», «русин», что, однако, вызвало бурю негодования среди лемковской русофильской интеллигенции и многочисленные протесты у поляков.

Политика П. Дунина-Борковского принесла скромные результаты. Период его воеводства был слишком коротким, чтобы в достаточно заметной степени развить какую-либо политику, но достаточно продолжительным, чтобы продвинуть во власть на территории Восточной Галиции, где господствовали польские национал-демократы, лагерь, связанный с Пилсудским. Однако они были не долгосрочными, будучи поглощенными кампанией крайнего антипольского крыла УНДО и других шовинистических украинских кругов, направленной против сторонников сотрудничества в своем же обществе ${ }^{20}$ и корректировкой курса властями. Главным результатом мер, предпринятых П. Дуниным-Борковским, для политических отношений в регионе стало то, что, вместо попыток силового давления и противостояния, главный акцент в политической тактике легальных украинских партий переместился в сторону конструктивных контактов с государственной администрацией. П. Дунин-Борковский сыграл очень

\footnotetext{
${ }^{19}$ Соляр I. УНДО і Польща в 1928-1930 рр.: пошук шляхів порозуміння // Україна: культурна спадщина, національна свідомість, державність. - Вип. 17/2008. - С. 180, 181.

${ }^{20}$ Piotrkewicz T. Kwestia ukraińska w Polsce w koncepcjach piłsudczyzny 1926 - 1930. - Warszawa, 1974. - S. 123.
} 
серьезную роль в политике нормализации и попытках польско-украинского согласия.

Предпринимались и достаточно масштабные попытки политической интеграции и у восточнославянских национальных меньшинств. 27-28 ноября 1929 г. состоялась украинско-белорусско-литовская конференция, в которой приняли участие такие политические партии, как УНДО, УСРП, УСДП, УСС, Белорусская Христианская Демократия, Крестьянский Союз, православные объединения и Литовский Национальный Комитет. УНДО представляли 13 послов и сенаторов, в частности весь президиум украинского клуба во главе с Д. Левицким. Целью конференции была выработка совместной тактики на парламентской арене и за ее пределами. Совместная работа завершилась созданием Согласительного Комитета, который, однако, не сыграл тогда заметной роли ${ }^{21}$ в деле налаживания и укрепления польско-украинских отношений.

Однако, в 1930 г. фактически происходит приостановка дальнейшего развития польско-украинского сотрудничества. Она была вызвана, с одной стороны, ужесточением подхода польских властей к национальному вопросу после выборов 1928 г. $^{22}$, на которых представители украинского национального политического движения получили наибольшее за всю историю II Речи Посполитой число представителей в польском Парламенте - 48 мест $^{23}$, что было следствием смягчения давления на украинскую политическую жизнь со стороны польских властей в 1926 - 1928 гг., с другой - необходимостью выживания в условиях экономического кризиса. Наступили годы польско-украинского конфликта.

Следует отметить, что легальная деятельность многочисленных партий и организаций составляла лишь видимую часть айсберга украинской национальной общественно-политической жизни. Противоположную его сторону представлял так называемый «нелегальный сектор», связанный, в первую очередь, с деятельностью двух совершенно новых для малорусского эт-

21 Лаврук Б. Парламентська діяльність Дмитра Левицького (1928-1930) // Краєзнавство. - № 3-4 2009. - С. 260.

22 Принесших рекордно высокие результаты представителям украинского нацменьшинства по всем «восточным кресам»

${ }^{23}$ В их числе - УНДО (а именно, практически все высшее руководство партии), УСРП, легальная ветвь КПЗУ - «СельРоб» (или Украинское Рабоче-Крестьянское Социалистическое Объединение - УРССО), образовавшие после преодоления раскола в украинской компартии украинский посольский клуб «Сельроб-Единство». носа и чрезвычайно динамичных по своему характеру сил - коммунизма и национализма. Это были две линии организованного сопротивления польским властям и политике полонизации, находящиеся за рамками легального украинского общественно-политического движения, к участию в которых украинское население толкала, главным образом, национальная политика Варшавы. При этом, в число сторонников данных политических сил входили те представители украинского населения, которые имел более развитое политическое сознание, нежели сторонники легальных партий. Это видно на примере того обстоятельства, что массы, стабильно голосовавшие за последних в течение межвоенного периода, не определяли политической повестки дня, и в итоге к концу 1930-х гг. сложилась ситуация, когда наиболее активную по своей динамике политическую деятельность развивали именно упомянутые выше две нелегальные силы, несмотря на все репрессии польских властей не терявшие, но даже наращивавшие численность своих активных сторонников. Также население выражало свой протест, если говорить о политических его формах, в виде массового уклонения от службы в польской армии ${ }^{24}$, бойкотирования выборов разных уровней.

КПЗУ, преобразованная в 1923 г. из КПВГ 25 , по данным 1930 г. на 55,3\% состояла из беднейшего крестьянства и батраков ${ }^{26}$, однако, эти слои населения составляли значительную долю всего восточнославянского населения Западной Украины в целом и Восточной Галиции в частности. Единственным путем к национальному и социальному освобождению западноукраинские коммунисты считали социалистическую революцию в Польше, которую совместно должны были осуществить рабочие и крестьяне всех национальностей. Также руководство КПЗУ выдвинуло лозунг соединения всех украинских земель в едином социалистическом государстве - Украинской Советской Республике. При этом для достижения национального освобождения необходимо было отказаться от национализма как самостоятельной цели.

Начало нового этапа развития политических отношений в Восточной Галиции совпало с распространением на Польшу мирового экономического кризиса. В

\footnotetext{
${ }^{24}$ Ольшанский П. Н. Рижский договор и развитие советскопольских отношений. 1921 - 1924 гг. - М., 1974. - С. 226.

${ }^{25}$ С осени 1923 г. сфера деятельности КПЗУ была расширена на Волынь, Холмщину, Полесье.

${ }^{26}$ Кугутняк Н. В. Указ. соч. - С. 16.
} 


\section{Политика и общество 2 (98) • 2013}

первой половине 1930-х гг. характеризовались большей степенью влияния на них политических партий и общественных организаций, включая нелегальный радикальный лагерь, все увеличивавший свою активность с каждым годом. Одним из рубежей в этнополитическом развитии украинцев стали выборы 1930 г., проводившиеся с гораздо более сильным нажимом со стороны польских властей, нежели двумя годами раньше. Он проявлялся в арестах руководителей и активистов разного уровня, разгромах партийных ячеек, запретительных мерах в отношении политической прессы. Наконец, заметно активизировался христианско-демократический лагерь.

В КПЗУ с начала 1930-х гг. появляется новый стимул деятельности в виде борьбы с влиянием своего антагониста по линии радикального движения - ОУН. В 1931 г. КПП и КПЗУ вновь выдвинули в качестве главного лозунга национально-освободительного движения на Западной Украине самоопределение вплоть до отделения от Польши, зафиксированное в программе партии. В октябре 1931 - марте 1932 г. число членов КПЗУ возросло с 2,5 до 4 тыс. чел. ${ }^{27}$, причем, около половины состава западноукраинской компартии составляли поляки и евреи. Находясь в подполье, коммунисты продолжали использовать в своей деятельности такие полулегальные организации, как: «Союз пролетариата городов и сел», «Украинское крестьянско-рабочее объединение» («Сель-Роб» ${ }^{28}$ ); распространяли влияние на членов профсоюзов, страховых обществ, читален «Просвиты», кружков «Ридной школы», экономических, спортивных и других массовых легальных организаций.

Остановимся также на характеристике украинского праворадикального лагеря в первой половине 1930-х гг. Одной из основных целей ОУН, образованной в 1929 г., была борьба с «прометеизмом» путем использования тактики «перманентной революции» ${ }^{29}$ и, в перспективе, установление «национальной диктатуры» украинцев на территории их собственного государства, из которого должны

\footnotetext{
${ }^{27}$ Мацкко А. Н. Деятельность компартии Польши и компартии Западной Белоруссии по организации трудящихся масс на борьбу против гнета буржуазии и помещиков (1918-1938 гг.): автореф. дисс. ... д-ра ист. наук. - Мн., 1968. - С. 50.

28 Это было самое мощное общеукраинское общественнополитическое движение межвоенного периода в Западной Украине.

${ }^{29}$ Мірчук П. Нарис історії ОУН. 1920 - 1939. - К., 2007. - С. 114.
}

быть изгнаны все «оккупанты». Она не была партией парламентского типа.

Одним из наиболее громких актов, совершенных праворадикалами в те годы, было убийство 29 сентября 1931 г. депутата польского Сейма от ППС Т. Голувки, одного из теоретиков «прометеизма» и идеолога «украинофильства». Были совершены два громких убийства: 22 марта 1932 г. - комиссара польской полиции Чеховського и 15 июня 1934 г. - министра внутренних дел Польши Б. Перацкого. После этих и подобных действий против руководства ОУН состоялись длительные судебные процессы, а убийство Перацкого повлекло за собой арест всего руководства объединенного с 1932 г. УВО-ОУН в Западной Украине. Неудивительно, что в 1932 г., массовая украинская военно-спортивная организация «Великий Луг» была переведена в подчинение Главного управления по физической и военной подготовке при Министерстве обороны Польши ${ }^{30}$ : туда активно проникали члены ОУН, занятые подготовкой кадров будущей украинской армии ${ }^{31}$.

Основным трендом в развитии украинского общественно-политического движения в начале 1930-х гг. являлось то, что события тех лет в Советской Украине - коллективизация, репрессии, «голодомор», практически положили конец советофильским тендециям в украинском движении. Антиукраинский террор в Приднепровье требовал от галичан, в чем были убеждены ведущие украинские общественно-политические деятели Восточной Галиции, взять на себя ответственность за судьбу всего украинства и подталкивал их к поиску путей понимания с польской стороной на антисоветском почве, с целью создания базы для освободительной борьбы в Приднепровье. Произошел переход к качественно новому этапу политических отношений, который характеризовался доминированием правовых элементов в политической деятельности основных субъектов политических отношений Восточной Галиции. Однако, этот аспект не получил всеобъемлющего распространения, охватив преимущественно центристские силы, став своего рода «визитной карточкой» их программы.

С 1933 г. «прогрессивные» польские и украинские общественные и политические деятели выпуска-

\footnotetext{
${ }^{30}$ Федевич К. К. Интеграция галицийских украинцев... - С. 17.

${ }^{31}$ Государственно-политический фактор в развитии украинской и белорусской наций (первая треть ХХ в.). Круглый стол // Белоруссия и Украина. История и культура. Ежегодник. 2004. - М., 2005. - С. 182.
} 
ли «Польско-украинский бюллетень», на страницах которого шел поиск взаимного соглашения, и вырабатывалась концептуально-идейная платформа для него. Программная концепция группы «Бюллетеня» основывалась на предположении о необходимости отклонить лозунги как национальной ассимиляции украинцев, так и преобразования государственного устройства Польши в духе автономизации или федерации. Признавалось целесообразным отказаться от объективных факторов, раздражающих украинское население, таких как запрет, наложенный в 1923 г. на использование самого понятия «украинец» и «украинский»; допустить без ограничений украинский язык к использованию в административных органах на территориях со смешанным этнически населением, свободное исполнение украинских патриотических народных песен и других проявлений национального самосознания в культурной сфере ${ }^{32}$. С целью расширения социальной базы для осуществления провозглашенных авторским коллективом «Бюллетеня» идей 8 июня 1933 г. было основано Польско-Украинское Товарищество во главе со С. Стемповским, включавшее в себя представителей украинской интеллигенции. При этом, все заинтересованные лица осознавали, что выстраивание комплексной системы межнациональных отношений в политической сфере не может быть одновременным процессом.

Не только польские общественные круги делали шаги навстречу украинской стороне в первой половине 1930-х гг. Львовский воевода Юзеф Рожнецкий, продолжая традицию своего предшественника П. Дунина-Борковского, практиковал встречи с украинской политической, культурной и бизнес-элитой, причем на первой из них, состоявшейся 30 февраля 1931 г., заявил, что в своей деятельности намерен опираться на все общество и отметил, что рассматривает украинцев как одного из хозяев на подведомственной ему территории ${ }^{33}$. В результате выборов в органы городских рад, прошедших в 1933 г., из 1480 мандатов украинцы получили 192, в их числе на УНДО приходилось $173^{34}$. Это было последним крупным успехом легального украинского

\footnotetext{
${ }^{32}$ Chojnowski A. A. Koncepcje polityki narodowościowej rządów polskich w latach 1921 - 1939. - Wroclaw, 1979. - S. 194.

${ }^{33}$ Федевич К. К. Указ. соч. - С. 164.

${ }^{34}$ Іваник М. Українсько-польські стосунки в органах місцевого самоврядування Галичини в 1919-1939 рр.: етнополітичний аспект // Україна: культурна спадщина, національна свідомість, державність. - Вип. 17/2008. - С. 172.
}

политического движения. В дальнейшем, после двух лет некоторого баланса в отношениях, начнется редукция легального присутствия украинского сегмента в политических отношениях Восточной Галиции.

Впрочем, стремительное развитие украинского общественно-политического движения в конце 1920-начале 1930-х гг. проходило на фоне внутренних идейных разногласий, усиления радикализма, сложной социальной ситуации на крессах в целом и жесткой репрессивной политики польского правительства. 15 сентября 1932 г., по причине заметной активизации антиправительственного партизанского движения в украинской деревне, польскими властями был запрещен Украинский посольский клуб «Сельроб-Единство».

Не прекращали свою деятельность военно-полевые суды. В 1931 - 1933 гг. в регионе ими было приговорено к смерти 25 человек, тогда как во всех центральных и западных воеводствах за тот же срок вынесено 70 смертных приговоров ${ }^{35}$. Сами условия в тюрьмах были настолько суровые, что не могли ускользнуть от внимания широкой европейской общественности.

Несмотря на возраставшую репрессивность политики Варшавы в отношении восточно-галицкого украинского политического движения, в среде польской общественности имелось довольно много деятелей, не разделявших взгляды правящих кругов. Они скажут своё слово уже в предвоенное десятилетие.

Таким образом, на рубеже 1920-1930-х гг. политические отношения в Восточной Галиции были заплетены в сложный узел, будучи наполнены многими противоречиями. Незрелость политических структур украинского населения региона вместе с молодостью восстановленной польской государственности можно отнести к первому уровню факторов политических отношений. Второй уровень характеризовался диаметральной противоположностью стратегических ориентиров ведущих легальных политических сил Восточной Галиции как польских, так и украинских, в сравнении друг с другом и даже внутри них самих, - наряду с тенденциями к лоялистскому характеру политических отношений как их ключевому принципу. К третье-

\footnotetext{
${ }^{35}$ Калинович В. I. Органи юстиції панськоі Польщі в Західній Україні (1918 - 1939 рр.) - апарат соціального і національного поневолення трудящих // Львівский державний университет ім. Івана Франка. Питання теоріі і практики радянського права. - Вип. 4. - Львів, 1958. // Львівский державний университет ім. Івана Франка. Питання теорії і практики радянського права. Випуск 4. - Львів, 1958. - С. 138.
} 


\section{Политика и общество 2 (98) • 2013}

му уровню можно отнести совокупность нелегальных политических движений, прежде всего - ОУН и КПЗУ, которые были исключительно деструктивно настроены к имевшейся модели общественнополитических отношений в регионе и тем самым являлись фактором давления на политические отношения первых двух уровней. Наконец, четвертый уровень представлял собой основную часть населения восточно-галицких воеводств, которую можно назвать потенциальным участником политических отношений, причем сам характер участия в них зависел от характера отношений на первых трех уровнях. И суть политических отношений в Восточной Галиции на рубеже 1920-1930-х гг. можно определить как проявление диалектической борьбы двух противоположностей - тенденций к легализации и, вместе с тем, - маргинализации украинского национального политического движения в условиях наибольшего подъема его легального сегмента.

\section{Библиография:}

1. Государственно-политический фактор в развитии украинской и белорусской наций (первая треть XX в.). Круглый стол // Белоруссия и Украина. История и культура. Ежегодник. 2004. - М., 2005. - С. $180-185$.

2. Дядюк М. С. Політизація українського жіночого руху в Галичині: 1921 - 1939 рр.: автореф. дис. ... канд. іст. наук. - Львів, 2002.

3. Іваник М. Українсько-польські стосунки в органах місцевого самоврядування Галичини в 1919-1939 pp.: етнополітичний аспект // Україна: культурна спадщина, національна свідомість, державність. Вип. 17/2008. - С. 166 - 176.

4. Калинович В. І. Органи юстиції панськоі Польщі в Західній Україні (1918 - 1939 рр.) - апарат соціального i національного поневолення трудящих // Львівский державний университет ім. Івана Франка. Питання теоріі і практики радянського права. - Вип. 4. - Львів, 1958. // Львівский державний университет ім. Івана Франка. Питання теорії і практики радянського права. Випуск 4. - Львів, 1958. - С. 135 - 153.

5. Коньков Д. И. Украина и Россия. Краткий очерк истории взаимных отношений. - М., 2005.

6. Косик В. Україна і Німеччина у Другій світовій війні. - Париж - Нью-Йорк - Львів, 1993.
7. Кугутняк Н. В. - Положение и революционноосвободительная борьба сельскохозяйственного пролетариата Западной Украины в 1929 - 1939 гг.: автореф. дисс. ... канд. ист. наук. - Одесса, 1985.

8. Лаврук Б. Парламентська діяльність Дмитра Левицького (1928-1930) // Краєзнавство. - № 3-4 2009. - С. $258-262$.

9. Любимов Л. Д. На рубеже новой Европы. Очерки современной Польши. - Париж, 1930.

10. Мацко А. Н. Деятельность компартии Польши и компартии Западной Белоруссии по организации трудящихся масс на борьбу против гнета буржуазии и помещиков (1918 - 1938 гг.): автореф. дисс. ... д-ра ист. наук. - Мн., 1968.

11. Мірчук П. Нарис історії ОУН. 1920 - 1939. - К., 2007.

12. Ольшанский П. Н. Рижский договор и развитие советско-польских отношений. 1921 - 1924 гг. M., 1974.

13. Постельжук О. Соціальна база українських угодовських партій Західної України (1918-1939рр.) // Проблеми історії України: факти, судження, пошуки: Міжвід. зб. наук. пр. Вип. 16(2)/2007. С. $261-268$.

14. Раевич Т. І. Український жіночий рух на Волині (1921-1939 роки). Автореф. дис.... канд. іст. наук. - Чернівці, 2006.

15. Соляр І. УНДО і Польща в 1928-1930 рр.: пошук шляхів порозуміння // Україна: культурна спадщина, національна свідомість, державність. Вип. 17/2008. - С. 177 - 185.

16. Стефанів В. Ставлення Андрея Шептицького до військово-політичної діяльності УВО, ОУН // Україна: культурна спадщина, національна свідомість, державність. Вип. 17/2008. - С. 356 - 361.

17. Федевич К. К. Галицькі украинці у Польщі 1920 - 1939 рр. (Інтеграція галицьких українців до Польської держави у 1920 - 1930-ті рр.). - К., 2009.

18. Chojnowski A. A. Koncepcje polityki narodowościowej rządów polskich w latach 1921 - 1939. - Wroclaw, 1979.

\section{References (transliteration):}

1. Dyadyuk M. S. Politizatsiya ukraïns'kogo zhinochogo rukhu v Galichini: 1921 - 1939 rr.: avtoref. dis. ... kand. ist. nauk. - L'viv, 2002. 
Государство и гражданское общество

2. Ivanik M. Ukraïns'ko-pol's'ki stosunki v organakh mistsevogo samovryaduvannya Galichini v 19191939 rr.: etnopolitichniy aspekt // Ukraïna: kul'turna spadshchina, natsional'na svidomist', derzhavnist'. Vip. 17/2008. - S. $166-176$.

3. Kalinovich V. I. Organi yustitsiï pans'koi Pol'shchi v Zakhidniy Ukraïni (1918 - 1939 rr.) - aparat sotsial'nogo i natsional'nogo ponevolennya trudyashchikh // L'vivskiy derzhavniy universitet im. Ivana Franka. Pitannya teorii i praktiki radyans'kogo prava. - Vip. 4. - L'viv, 1958. // L'vivskiy derzhavniy universitet im. Ivana Franka. Pitannya teoriï i praktiki radyans'kogo prava. Vipusk 4. - L'viv, 1958. - S. $135-153$.

4. Kon'kov D. I. Ukraina i Rossiya. Kratkiy ocherk istorii vzaimnykh otnosheniy. - M., 2005.

5. Kosik V. Ukraïna i Nimechchina u Drugiy svitoviy viyni. - Parizh - N'yu-York - L'viv, 1993.

6. Kugutnyak N. V. - Polozhenie i revolyutsionnoosvoboditel'naya bor'ba sel'skokhozyaystvennogo proletariata Zapadnoy Ukrainy v 1929 - 1939 gg.: avtoref. diss. ... kand. ist. nauk. - Odessa, 1985.

7. Lavruk B. Parlaments'ka diyal'nist' Dmitra Levits'kogo (1928-1930) // Kra€znavstvo. - № 3-4 2009. - S. $258-262$.

8. Lyubimov L. D. Na rubezhe novoy Evropy. Ocherki sovremennoy Pol'shi. - Parizh, 1930.

9. Matsko A. N. Deyatel'nost' kompartii Pol'shi i kompartii Zapadnoy Belorussii po organizatsii trudyash- chikhsya mass na bor'bu protiv gneta burzhuazii i pomeshchikov (1918 - 1938 gg.): avtoref. diss. ... d-ra ist. nauk. - Mn., 1968.

10. Mirchuk P. Naris istorii OUN. $1920-1939$. - K., 2007.

11. Ol'shanskiy P. N. Rizhskiy dogovor i razvitie sovetsko-pol'skikh otnosheniy. 1921 - 1924 gg. - M., 1974.

12. Postel'zhuk O. Sotsial'na baza ukraïns'kikh ugodovs'kikh partiy Zakhidnoï Ukraïni (1918-1939 rr.) // Problemi istoriï Ukraïni: fakti, sudzhennya, poshuki: Mizhvid. zb. nauk. pr. Vip. 16(2)/2007. - S. 261 -268 .

13. Raevich T. I. Ukraïns'kiy zhinochiy rukh na Volini (1921-1939 roki). Avtoref. dis.... kand. ist. nauk. Chernivtsi, 2006.

14. Solyar I. UNDO i Pol'shcha v 1928-1930 pp.: poshuk shlyakhiv porozuminnya // Ukraïna: kul'turna spadshchina, natsional'na svidomist', derzhavnist'. - Vip. 17/2008. - S. 177 - 185.

15. Stefaniv V. Stavlennya Andreya Sheptits'kogo do viys'kovo-politichnoï diyal'nosti UVO, OUN // Ukraïna: kul'turna spadshchina, natsional'na svidomist', derzhavnist'. Vip. 17/2008. - S. 356 - 361.

16. Fedevich K. K. Galits'ki ukraintsi u Pol'shchi 1920 - 1939 rr. (Integratsiya galits'kikh ukraïntsiv do Pol's'koï derzhavi u 1920 - 1930-ti rr.). - K., 2009.

17. Chojnowski A. A. Koncepcje polityki narodowościowej rządów polskich w latach 1921 - 1939. - Wroclaw, 1979. 